DOI: https://doi.org/10.47405/mjssh.v6i10.1091

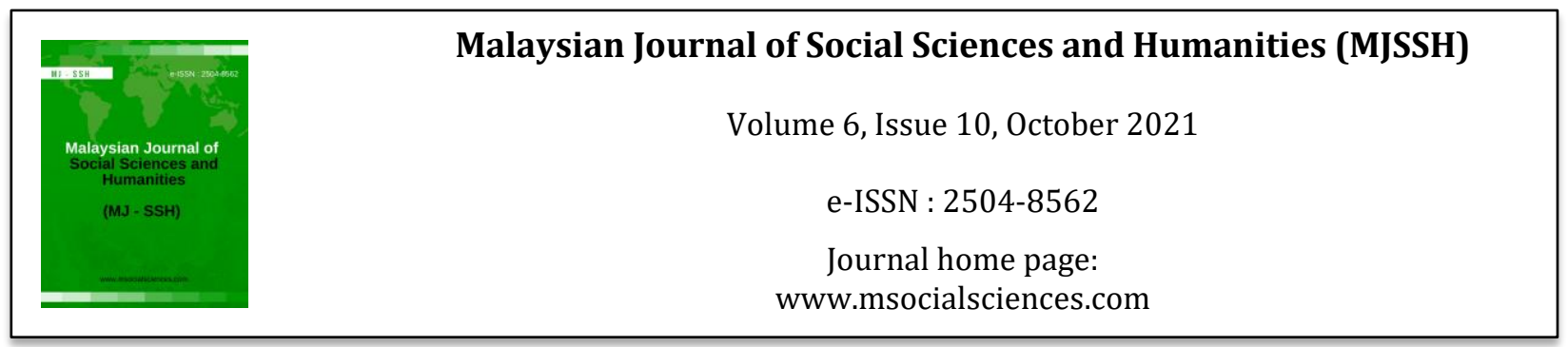

\title{
Faktor Penglibatan, Ciri Personaliti dan Cabaran Usahawan Siswazah dalam Bidang Keusahawanan
}

\author{
Mazdan Ali Amaran', Mohd Sharizam Hamzah' \\ ${ }^{1}$ Fakulti Seni Gunaan dan Kreatif, Universiti Malaysia Sarawak (UNIMAS), Kota Samarahan, Sarawak, Malaysia \\ Correspondence: Mazdan Ali Amaran (amazdan@unimas.my)
}

\begin{abstract}
Abstrak
Pasaran pekerjaan negara yang terhad masa kini tidak mampu menampung ribuan jumlah graduan yang keluar setiap tahun dan seterusnya akan menyebabkan pengangguran dalam kalangan graduan. Oleh itu bekerja sendiri merupakan kerjaya yang harus diberi perhatian sebagai kerjaya alternatif oleh para graduan di sebalik makan gaji. Kajian ini mengkaji dan mengenal pasti kompetensi ciri-ciri usahawan yang berjaya serta faktor pendorong dan cabaran penglibatan lepasan siswazah dalam bidang keusahawanan ini. Seramai 20 orang usahawan siswazah telah ditemu bual secara bersemuka dan perisian N.Vivo versi 12.0 digunakan bagi menganalisis hasil temu bual tersebut secara kualitatif. Hasil temu bual mendapati simpanan sendiri dan ahli keluarga adalah merupakan sumber utama modal perniagaan. Minat dengan sikap, motivasi dan kemahiran diri adalah yang mendorong mereka untuk menjadi usahawan. Agresif, berwawasan dan berani mengambil risiko merupakan faktor kejayaan mereka. Modal, persaingan dan pemasaran merupakan cabaran utama yang perlu dihadapi.
\end{abstract}

Kata kunci: usahawan siswazah, bekerja sendiri, keusahawanan, siswazah

\section{Factors of Involvement, Characteristics, Challenges among Graduates Entrepreneur in the field of Entrepreneurship}

\begin{abstract}
The current job market in the country is not able to accommodate thousands of graduates produced each year that results to unemployment among graduates. Self-employed as entrepreneur is career that should be given attention as alternative career by the graduates other than salaried job. This study investigates and identify the competency character of success entrepreneur and motivator factor and challenges graduates involvement in the entrepreneurship. Face-to-face interview involving 20 entrepreneur graduates and using qualitative software N.Vivo version 9.0 to analyse the interview data. Interview results found that own savings and family members are the main source of their business capital. Interest with attitude, motivation and personal skill are the factors that motivate them to be an entrepreneur. Aggressive, having a vision and dare to take risk are their success factors. Capital, competition and marketing are the key challenges that need to be faced.
\end{abstract}

Keywords: graduates entrepreneur, self employed, entrepreneurship, graduates 


\section{Pengenalan}

Data dalam Jadual 1 menunjukkan taraf pekerjaan graduan mengikut peringkat pengajian dari Laporan Kajian Pengesanan Graduan Kementerian Pengajian Tinggi bagi tahun 2008 menunjukkan. Disini jelas menunjukkan daripada 41,470 orang graduan yang bekerja pada tahun 2008, hanya 1.1 peratus daripada jumlah graduan iaitu seramai 456 graduan sahaja yang membuat pilihan untuk bekerja sendiri dan menjadi seorang usahawan selepas tamat pengajian.

Jadual 1: Taraf Pekerjaan Graduan Mengikut Peringkat Pengajian, 2008

\begin{tabular}{|c|c|c|c|c|c|c|c|}
\hline \multirow[b]{2}{*}{$\begin{array}{l}\text { Taraf } \\
\text { Pekerjaan }\end{array}$} & \multicolumn{6}{|c|}{ Peringkat Pengajian } & \multirow[b]{2}{*}{ Keseluruhan } \\
\hline & Ph.D & Sarjana & $\begin{array}{l}\text { Ijazah } \\
\text { Pertama }\end{array}$ & Diploma & Sijil & Profesional & \\
\hline Tetap & 86.4 & 80.3 & 64.1 & 73.4 & 37.7 & 83.7 & 60.9 \\
\hline Kontrak & 8 & 10.2 & 20.2 & 14.23 & 23 & 11.6 & 20 \\
\hline Sementara & 3.9 & 7.3 & 13.9 & 10.43 & 33.6 & 4.6 & 16.5 \\
\hline $\begin{array}{l}\text { Bekerja } \\
\text { Sendiri } \\
\text { Bekeria }\end{array}$ & 1.7 & 1.9 & 1.1 & 1.03 & 2.3 & - & 1.4 \\
\hline $\begin{array}{l}\text { Bekerja } \\
\text { Dengan }\end{array}$ & - & 0.3 & 0.8 & & 3.5 & - & 1.2 \\
\hline $\begin{array}{l}\text { Keluarga } \\
\text { Jumlah }\end{array}$ & 100 & 100 & 100 & $\begin{array}{l}0.93 \\
100\end{array}$ & 100 & 100 & 100 \\
\hline
\end{tabular}

Sumber: Laporan Kajian Pengesanan Graduan 2008, Kementerian Pengajian Tinggi

Daripada data yang ditunjukkan jelas menunjukkan bahawa budaya bekerja sendiri sebagai seorang usahawan masih merupakan kerjaya 'asing' bagi kebanyakan graduan. Pihak Kementerian Pengajian Tinggi di dalam Pelan Strategik Transformasi Pendidikan Tinggi Negara telah menggariskan peranan institusi pengajian tinggi negara melahirkan modal insan yang lebih berinovasi iaitu merupakan salah satu ciri penting keusahawanan (Kementerian Pengajian Tinggi, 2007). Kementerian Pengajian Tinggi (KPT) menyasarkan, sekurang-kurangnya lima peratus lepasan IPTA menceburi bidang keusahawanan mulai tahun 2011 (Berita harian, 2010).

Para graduan pada era ini perlu mempunyai tahap pengetahuan dan inovasi yang tinggi untuk mampu bersaing dan berjaya di arena antarabangsa dan bersedia untuk menghadapi realiti baru ini. Budaya keusahawanan dalam kalangan pelajar dan graduan etnik Cina telah tertanam dengan agak teguh. Kebanyakan mereka tidak suka makan gaji, mungkin kerana mahu bebas dan tidak terikat dan dapat melakukan beberapa pekerjaan pada sesuatu masa dengan pulangan kewangan yang lebih lumayan. Tidak ramai juga graduan yang melibatkan diri dalam aktiviti keusahawanan ketika di IPT namun disebabkan oleh faktor-faktor lain seperti minat kepada dunia perniagaan yang telah mendorong mereka untuk menjadi seorang usahawan sehingga kini. Kebanyakan daripada usahawan memulakan perniagaan selepas mengambil masa beberapa tempoh tertentu seperti setahun sehingga 4 tahun selepas tamat pengajian untuk menimba pengalaman dengan bekerja terlebih dahulu sebelum memulakan perniagaan sendiri (Mazdan, 2011). Pemilihan jenis perniagaan juga memainkan peranan penting dalam memastikan kejayaan sesuatu perniagaan tersebut. Oleh itu, objektif kajian ini dilakukan bagi mengenal pasti kompetensi ciri-ciri usahawan siswazah yang berjaya menceburi bidang keusahawanan ini serta mengenal pasti faktor pendorong dan cabaran penglibatan usahawan siswazah dalam bidang keusahawanan.

\section{Kajian Literatur}

Berdasarkan hasil kajian yang lepas, menurut (Ronstadt, 1985) percaya bahawa kebanyakan manusia termasuk seorang usahawan tidak pernah terfikir untuk menjadikan bidang keusahawanan sebagai kerjaya. Oleh itu, Ronstadt melihat bahawa bidang keusahawanan merupakan satu prospek kerjaya yang sangat sesuai untuk dipilih oleh seseorang pelajar atau mahasiswa yang akan menamatkan pengajian. 
Faktor latar belakang usahawan merupakan antara faktor yang terpenting dalam mendorong seseorang itu untuk menceburi bidang keusahawanan (Zafir \& Fazilah, 2003). Latar belakang ini dilihat daripada dua aspek iaitu faktor latar belakang keluarga dan faktor latar belakang akademik. Ini disokong oleh (Wang \& Wong, 2004) daripada kajian yang mereka lakukan terhadap graduan Universiti Singapura terdapat kesan yang signifikan ke atas 3 faktor latar belakang iaitu pengalaman daripada latar belakang perniagaan keluarga, jantina dan latar belakang akademik yang mendorong pelajar atau graduan mereka untuk cenderung melibatkan diri dalam bidang keusahawanan. Selain faktor latar belakang, menurut (Yep, 1985) motivasi keusahawanan juga merupakan dorongan atau desakan yang kuat pada seseorang untuk menjadi usahawan. Kenyataan ini disokong oleh (Khaairuddin, 1996) yang menjelaskan motivasi sebagai faktor penting dalam menentukan tahap kecemerlangan seseorang. Menurut kajian yang telah dijalankan oleh (Mohd Hassan, 2007) pula menunjukkan majoriti graduan dan Alumni UTM yang menceburi bidang keusahawanan bersetuju bahawa faktor motivasi, faktor sikap dan faktor kemahiran menjadi faktor terpenting dalam mempengaruhi mereka menjadi seorang usahawan manakala faktor latar belakang kurang mempengaruhi mereka untuk menceburi bidang tersebut.

Pembudayaan keusahawanan yang mendorong kepada aktiviti keusahawanan juga memainkan peranan yang penting bagi melahirkan seorang usahawan graduan. Kajian yang dijalankan oleh (Shahrin \& Hamalatha, 2010) mendapati daripada 126 orang responden, 29 peratus responden yang kurang berminat dengan bidang keusahawanan ini. Ini kerana kurangnya menyertai program-program keusahawanan, kurang peka terhadap bidang keusahawanan dan tidak mengenali usahawan tempatan yang telah berjaya yang boleh dijadikan role model. Namun begitu masih lagi terdapat 65.7 peratus responden yang mempunyai ciri-ciri usahawan seperti penyelesaian masalah dan tugas, sentiasa mencuba, kerja yang mencabar dan bijak menyelesaikan masalah mengatakan program-program keusahawanan yang dilaksanakan banyak memberi dorongan dan impak yang positif dalam membantu mereka menceburi bidang keusahawanan. (Hanim et al., 2009) pula mendapati pembangunan pembudayaan keusahawanan dapat dijayakan apabila perlaksanaan Program Tunas Bistari berjalan dengan efektif dan dapat menarik minat pelajar terhadap keusahawanan. Dan disokong oleh kajian (Kent, 1990) yang menjelaskan bahawa pendidikan keusahawanan harus difokuskan kepada tiga dimensi iaitu dimensi menerapkan kesedaran keusahawanan, dimensi kemahiran keusahawanan dan dimensi kemahiran penilaian diri. Pendidikan keusahawanan menekankan proses pembinaan manusia yang berorientasikan keusahawanan. Hanim et al. (2010) pula mengkaji tentang hubungan antara tahap kompetensi keusahawanan dengan pendedahan keusahawanan yang diterima oleh pelajar dan mereka mendapati pelajar yang mendapat pendedahan secara formal atau pengetahuan tentang bidang keusahawanan adalah lebih berjaya dalam bidang keusahawanan atau dengan kata lain mempunyai tahap kompetensi keusahawanan yang tinggi.

\section{Metod Kajian}

Peserta kajian ini terdiri daripada seramai 20 orang usahawan lepasan siswazah yang terdiri daripada lepasan IPT di seluruh Malaysia. Pemilihan sampel kajian menggunakan kaedah Snowball iaitu seorang usahawan siswazah akan mencadangkan nama seorang lagi usahawan siswazah sehingga lengkap 20 orang usahawan siswazah yang diperolehi. Kaedah temu bual terancang dilakukan secara bersemuka dengan 20 orang usahawan siswazah berkenaan. Kaedah analisis data yang digunakan dalam kajian ini adalah menggunakan kaedah kualitatif. Penginterpretasian hasil temu bual bersama usahawan siswazah berkenaan akan dianalisis menggunakan perisian N.Vivo versi 12.0.

\section{Hasil Kajian}

\section{Profil Usahawan Siswazah}

Sejumlah 20 orang usahawan telah ditemu bual, 15 (75\%) responden lelaki dan 5 (25\%) responden perempuan. Kebanyakan usahawan yang telah ditemu bual adalah dalam lingkungan umur antara 25 tahun sehingga 29 tahun iaitu 9 usahawan (45\%) dan yang lain 3 usahawan (15\%) berada di kumpulan umur 20 hingga 24 tahun, 4 usahawan (20\%) 30 hingga 34 tahun, 1 usahawan (5\%) 35 hingga 39 tahun, 
2 (10\%) 45 hingga 49 tahun, serta 1 (5\%) berumur 50 tahun dan ke atas. Hampir kesemua responden (19 usahawan) yang ditemu bual adalah Melayu dan hanya seorang Bumiputera Sabah. Seramai 11 orang (55\%) usahawan yang ditemu bual telah berkahwin manakala selebihnya 9 (45\%) masih bujang. Usahawan dengan pendapatan bulanan antara RM 2001 hingga RM 5000 dan memperoleh RM 5000 dan ke atas adalah antara yang paling ramai iaitu masing-masing, 7 usahawan (35\%) dan selebihnya memperoleh pendapatan antara RM 1501 hingga RM 2000 (15\%), RM 1001 hingga RM 1500 (5\%) dan kurang daripada RM 500 (10\%). Usahawan yang memiliki Ijazah Pertama merupakan usahawan yang paling ramai ditemu bual iaitu 12 usahawan (60\%) dan selebihnya Ph.D (5\%), Sarjana (20\%), Diploma (10\%) serta Sijil hanya seorang (5\%).

\section{Penglibatan Usahawan Siswazah dalam Aktiviti Perniagaan}

Berdasarkan Rajah 1 menunjukkan perhubungan penglibatan usahawan graduan dalam bidang keusahawanan dengan keadaan perniagaan seperti dalam Kajian Pengesanan Graduan (KPG), status perniagaan dan perniagaan sampingan. Biodata usahawan telah dijelaskan dalam bahagian 3.1 dan seterusnya kajian melihat keadaan perniagaan usahawan. Sebelum dibincangkan dengan lebih lanjut lagi, kajian mendapati hanya 15 usahawan (85\%) tidak pernah terlibat dengan aktiviti keusahawanan semasa pengajian di IPT manakala hanya 5 usahawan (15\%) sahaja yang terlibat dalam aktiviti keusahawanan di IPT. Kebanyakan graduan yang menceburi bidang keusahawanan ini selepas mengambil masa beberapa tempoh tertentu seperti setahun, dua tahun dan ada juga responden yang mengambil masa 17 tahun sebelum memulakan perniagaan iaitu 10 usahawan (50\%) dan selebihnya memulakan perniagaan sebelum tamat pengajian 9 usahawan $(45 \%)$ dan sejurus tamat pengajian 1 usahawan $(5 \%)$.

Rajah 1: Penglibatan Usahawan Siswazah dalam aktiviti perniagaan

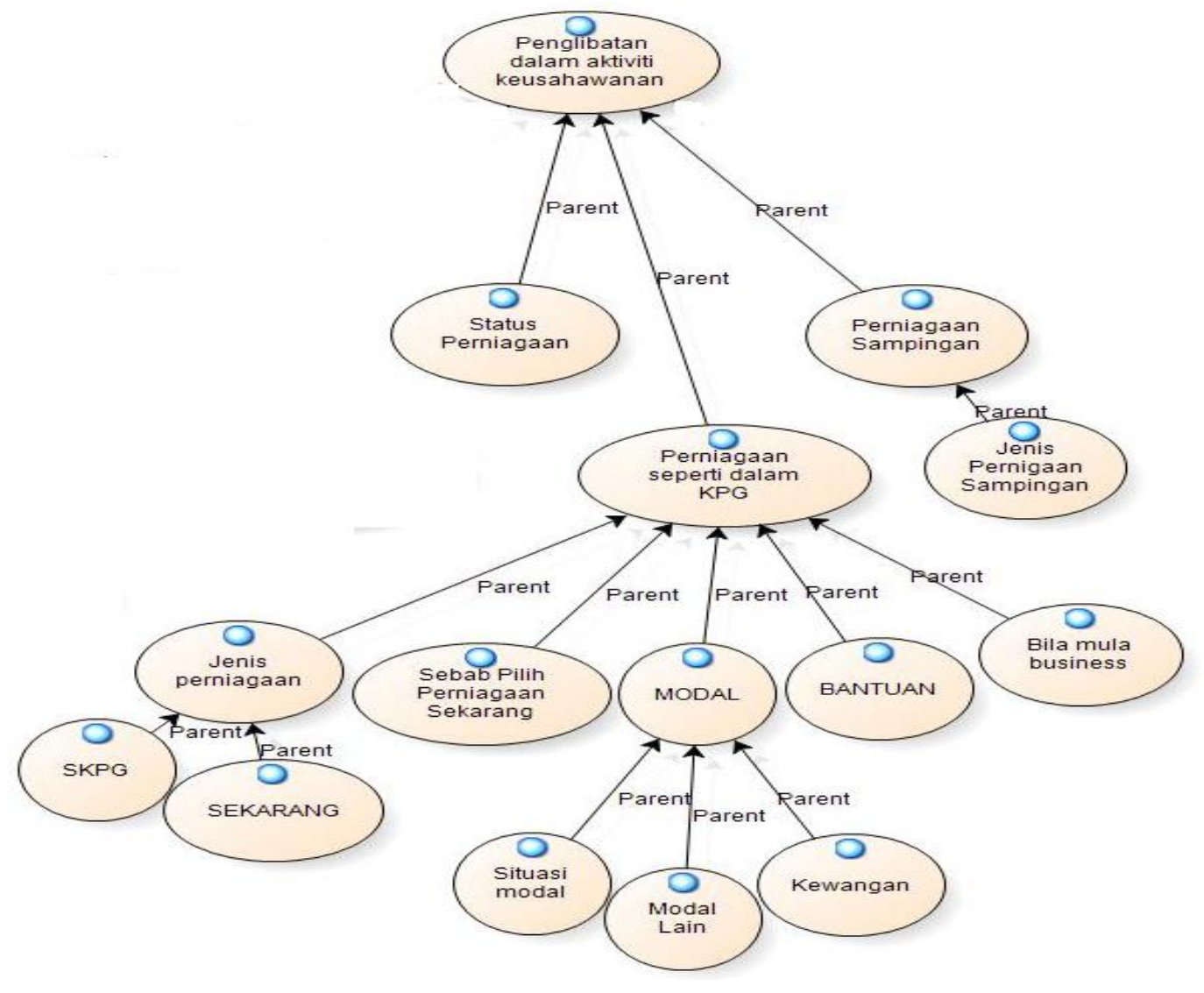

Daripada segi bantuan kewangan, teknikal atau pemasaran pula 16 usahawan (80\%) menyatakan tiada bantuan daripada mana-mana pihak manakala 4 usahawan (20\%) menyatakan mendapat bantuan daripada beberapa pihak seperti bank, pembekal MEDEC dan MIDA. Manakala sumber modal yang diperoleh untuk memulakan perniagaan 18 usahawan (90\%) menyatakan daripada simpanan sendiri, 3 
usahawan (15\%) masing-masing daripada sumber pinjaman bank dan ibu bapa serta selebihnya mendapatkan sumber modal daripada saudara-mara, meminjam daripada rakan dan menggunakan modal pusingan yang ada.

Jenis perniagaan yang diceburi oleh usahawan antaranya adalah printing, saham unit (unit trust), perkhidmatan, jualan langsung (multi level marketing), blogshop, kejuruteraan, fotografi dan kraftangan. Namun ada beberapa usahawan yang berubah daripada jenis perniagaan yang dijalankan iaitu antaranya daripada jenis perniagaan pertanian kepada kontraktor, perniagaan keropok kepada jualan langsung, perniagaan printing kepada fotografi dan jenis perniagaan jualan langsung kepada kejuruteraan. Ini disebabkan oleh menurut beberapa usahawan mereka mempunyai terlalu ramai pesaing dalam pasaran perniagaan dahulu, kekurangan modal untuk meneruskan perniagaan sebelum ini, kurang permintaan dan jenis perniagaan dahulu tidak sesuai dengan ilmu yang dipelajari di IPT.

Terdapat beberapa sebab yang mendorong usahawan memilih jenis perniagaan yang diceburi sekarang ini iaitu mereka memilih utuk menceburi dalam sesuatu jenis perniagaan mengikut kemahiran, kepakaran, kelulusan dan ilmu yang dipelajari di IPT. Terdapat juga usahawan yang menceburi bidang keusahawanan ini oleh kerana mewarisi perniagaan keluarga yang telah membangun. Kajian usahawan terhadap sesuatu pasaran perniagaan juga amat penting dalam mengenal pasti jenis perniagaan yang ingin diceburi. Minat yang mendalam pada sesuatu jenis perniagaan itu juga merupakan salah satu sebab dalam penubuhan perniagaan oleh seseorang usahawan itu.

Kebanyakan usahawan yang ditemu bual merupakan status perniagaan pemilikan tunggal iaitu 9 usahawan (45\%) manakala $8(40 \%)$ berstatuskan Sendirian Berhad dan selebihnya perniagaan perkongsian, sambilan dan tidak berdaftar. Daripada 20 orang responden yang ditemu bual, hanya 3 usahawan sahaja (15\%) yang menjalankan perniagaan sampingan dan selebihnya 17 usahawan (85\%) yang tidak menjalankan perniagaan sampingan dan hanya tumpu kepada perniagaan yang sedang dijalankan sekarang ini. Antara jenis perniagaan sampingan yang diceburi oleh 3 orang usahawan ini adalah menjual kerepek, menjual produk jualan langsung dan menjual alat ganti kereta.

\section{Perkembangan Perniagaan}

Perkembangan perniagaan yang diukur daripada aspek perubahan yang dilakukan oleh usahawan keatas perniagaan yang dijalankan sekarang adalah daripada bentuk kepelbagaian produk, penambahan bilangan pekerja, pasaran dan penambahan bilangan cawangan. Kebanyakan usahawan juga melakukan perubahan dalam pasaran perniagaan mereka bagi memenuhi permintaan pengguna, kepelbagaian dalam produk yang ditawarkan dan penambahan cawangan perniagaan ke tempat lain.

Pembaharuan dan inovasi yang dilakukan oleh usahawan dalam operasi perniagaan mereka kebanyakannya mencipta satu produk yang baru untuk dipasarkan dan memperkembangkan fungsi satu produk yang ada kepada fungsi yang pelbagai. Pembaharuan daripada segi pasaran pula ada usahawan yang mempunyai segmentasi pasaran iaitu meletakkan sesuatu pasaran dan dibezakan mengikut gelagat pelanggan pada satu-satu tempat yang ingin dipasarkan. Pembaharuan daripada aspek promosi yang dilakukan oleh usahawan dengan mempromosikan produk dari kawasan ke kawasan yang lain, promosi daripada pelanggan tetap kepada pelanggan baru dan menggunakan strategi pemberian cenderahati atau hadiah kepada pelanggan tetap yang setia. Aspek pembaharuan yang dilakukan oleh usahawan juga dapat dilihat dengan penggunaan IT atau komputer dalam perniagaan seseorang usahawan iaitu dengan menggunakan laman sosial facebook, blog, email, dan laman web untuk mempromosikan produk mereka.

Kebanyakan usahawan menyatakan keadaan perniagaan sekarang mereka bertambah baik dan begitu juga dengan keadaan perniagaan mereka pada 3 tahun sebelum ini. Namun terdapat juga usahawan yang menyatakan keadaan perniagaan mereka tidak berubah pada waktu sekarang dan 3 tahun sebelumnya. Terdapat 4 jenis perancangan yang dikenal pasti bagi menjamin perniagaan mereka pada masa akan datang. Antara perancangan yang dikemukakan oleh usahawan adalah membesarkan saiz perniagaan dengan mencari tender projek yang banyak, menambah cawangan melalui skim francais dan menambah rakan kongsi daripada pelbagai negeri untuk tujuan rangkaian (networking), perancangan perniagaan 
sehingga ke peringkat nasional dan ke peringkat antarabangsa. Namun terdapat usahawan yang hanya mempunyai perancangan menjalankan operasi perniagaan di dalam negara sahaja oleh kerana sumber modal yang terhad dan tidak cukup pengalaman dalam menguruskan perniagaan sekiranya beroperasi di luar negara.

\section{Faktor Pendorong}

Berdasarkan Rajah 2 menunjukkan faktor pendorong yang mendorong mereka menjadi seorang usahawan yang berjaya.

\section{Rajah 2: Faktor Pendorong}

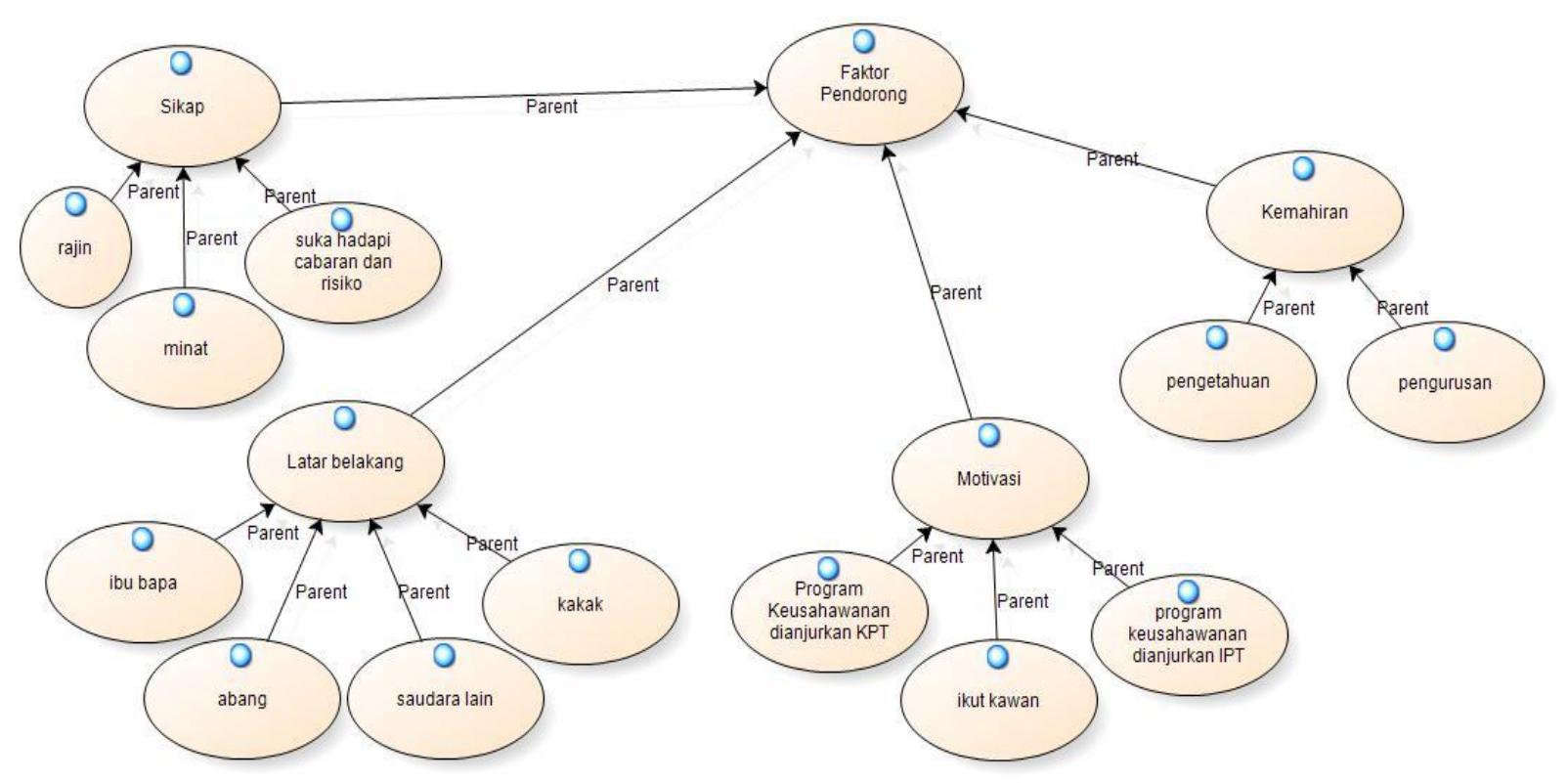

Terdapat 4 faktor pendorong yang dihubungkan dalam analisis kualitatif ini iaitu latar belakang, sikap, motivasi dan kemahiran. Ramai usahawan yang ditemu bual mempunyai sikap minat yang tinggi dalam menjalankan sesuatu perniagaan tersebut dan semua usahawan mempunyai pandangan yang sama iaitu sekiranya tiada minat dalam melakukan sesuatu kerja maka hasil yang diperoleh tidak sebaik yang dijangkakan. Mereka juga mempunyai sikap rajin dan tekun dalam melakukan sesuatu kerja sehingga berjaya. Mereka mempunyai sikap yang suka menghadapi cabaran dan tidak gentar dengan risiko atau musibah yang datang. Selain itu, sikap usahawan juga termasuklah sentiasa berdikari dan keinginan untuk berjaya dalam diri.

Faktor latar belakang juga memainkan peranan dalam mendorong mereka untuk menjadi seorang usahawan. Dimana ada di antara usahawan yang ditemu bual mewarisi perniagaan ahli keluarga yang sedia ada seperti meneruskan perniagaan ibu bapa, abang, kakak, dan saudara-mara lain seperti pakcik dan makcik. Motivasi yang kuat dalam diri memainkan peranan yang penting dalam menggalakkan seseorang itu menceburi bidang keusahawanan. Ada usahawan yang memperoleh motivasi diri dengan mengikuti beberapa program yang dianjurkan oleh KPT dan IPT masing-masing seperti Program Tunas Mekar UiTM dan Bengkel Keusahawanan di IKM.

Namun ada juga usahawan yang memperoleh motivasi diri dengan mengikut kawan yang sudah berjaya menjadi usahawan dan menampakkan hasil yang lumayan sebagai tarikan. Diantara faktor-faktor pendorong yang dinyatakan diatas faktor kemahiran adalah faktor yang paling penting dalam menggalakkan seseorang itu untuk menjadi usahawan. Ini kerana ada usahawan yang mengatakan walaupun ada sikap rajin, minat atau memotivasikan diri dengan menghadiri seberapa banyak program keusahawanan sekalipun tidak tentu seseorang itu pandai menguruskan segalanya tanpa ada kemahiran yang cukup untuk dijadikan bekalan. Sekiranya mempunyai kemahiran, kepakaran ataupun ilmu dalam 
sesuatu bidang seseorang itu akan menjadi lebih mudah untuk menguruskan perniagaan yang mereka jalankan.

\section{Ciri-ciri Usahawan Siswazah}

Berdasarkan Rajah 3 menunjukkan 5 ciri utama bagi seseorang usahawan yang didapati daripada hasil temu bual yang dijalankan iaitu rangkaian atau networking, wawasan, agresif, risiko, dan akaun. Ciri pertama yang dinyatakan oleh kebanyakan usahawan ini adalah agresif terhadap kerja yang dilakukan. Agresif ini termasuklah mempunyai ketahanan diri dalam menghadapi cabaran, melakukan kerja secara berterusan tanpa mengira batas masa, bertenaga dan dinamik. Terdapat usahawan mengatakan bidang yang diceburi ini memerlukan tahap pengorbanan yang tinggi seperti pengorbanan masa bersama keluarga, pengorbanan dalam memenuhi kehendak dan pengorbanan wang yang banyak. Ciri seterusnya adalah mempunyai rangkaian atau networking dengan agensi-agensi swasta mahupun kerajaan untuk memperkembangkan lagi perniagaan mereka dan mencari lebih banyak peluang perniagaan. Antara sistem rangkaian yang disebutkan oleh usahawan ini adalah sistem francais yang dapat menambahkan lagi cawangan perniagaan dan memperkembangkan lagi perniagaan mereka.

\section{Rajah 3: Ciri-ciri Usahawan}

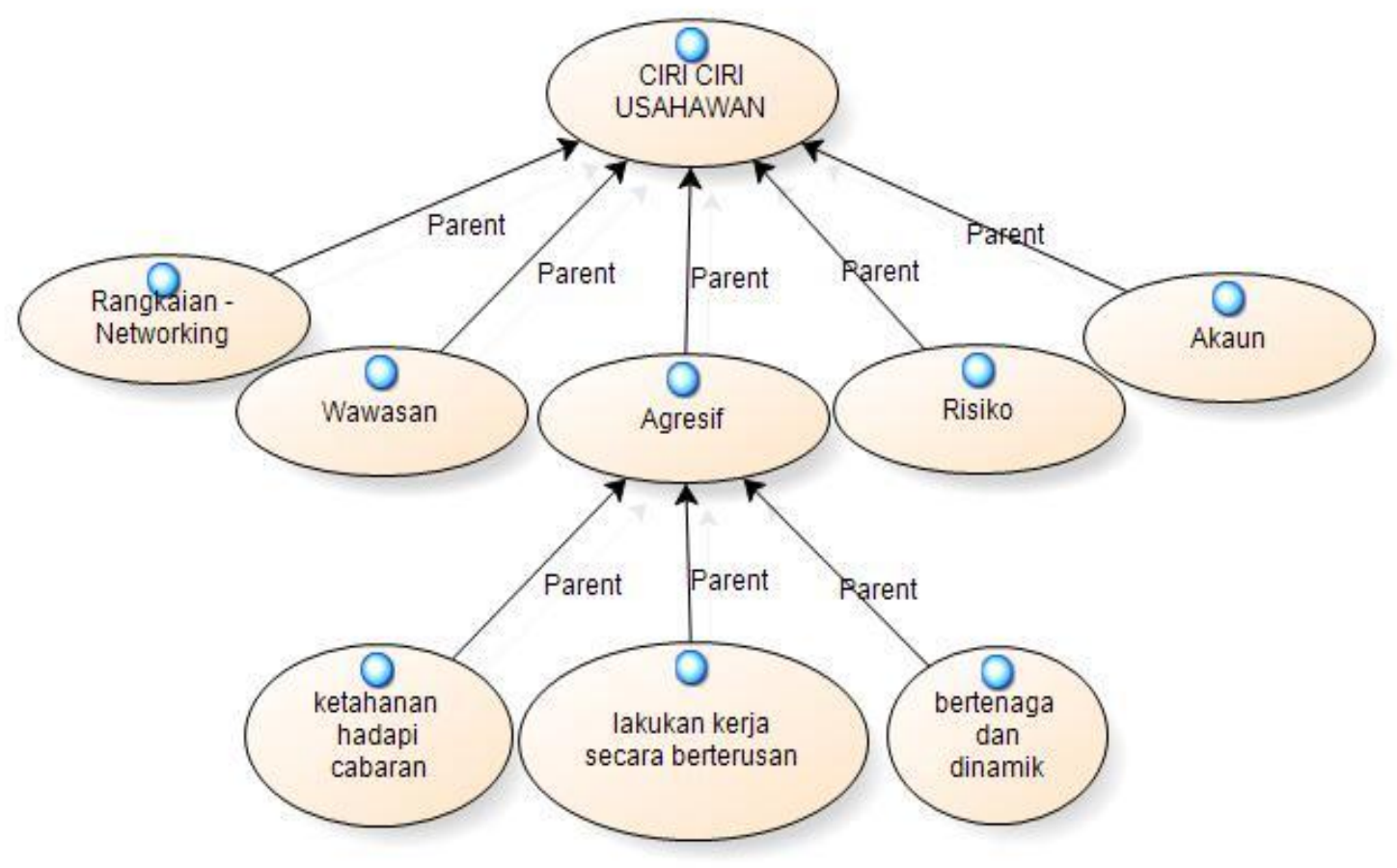

Selain itu,usahawan yang ditemu bual mempunyai wawasan yang tinggi dalam diri mereka. Setiap usahawan mempunyai misi dan visi serta objektif ke arah mencapai hala tuju dalam perniagaan mereka. Usahawan mempunyai daya ketahanan dalam mengambil risiko yang dilalui. Ini kerana usahawan adalah seorang pengambil risiko, suka dan gemar dengan risiko serta sentiasa berwaspada. Ini kerana mereka bijak mengatur strategi perniagaan bagi memastikan perniagaan yang diceburi tidak berisiko. Seseorang usahawan juga memerlukan pengetahuan dan kemahiran dalam pengurusan sistem perakaunan yang sempurna. Ini bertujuan bagi memastikan pengurusan kewangan perniagaan dalam diatur dengan strategik supaya risiko kerugian dapat diminimumkan.

\section{Cabaran dan Halangan}

Rajah 4 menunjukkan cabaran dan halangan yang sering dihadapi oleh seseorang usahawan. Antara yang dikaitkan adalah masalah modal, pekerja, persaingan, pemasaran, dan lain-lain cabaran. Masalah sumber modal yang tidak mencukupi adalah menjadi satu perkara yang biasa bagi golongan usahawan. 
Namun perkara ini adalah satu cabaran yang mesti dilalui oleh semua usahawan bagi menjadikan mereka lebih matang dalam menguruskan kewangan perniagaan.

Selain itu, gelagat pekerja dan bilangan pekerja juga menjadi satu cabaran kepada usahawan. Kebanyakan pekerja mempunyai permintaan gaji yang tinggi dan ini akan menyebabkan peningkatan dalam kos perniagaan. Usahawan juga mempunyai pekerja yang kurang kerana kesukaran untuk mendapat pekerja yang setia pada satu-satu kerja dan kesukaran mendapat pekerja yang mahir. Persaingan juga merupakan satu perkara yang biasa dalam sesebuah perniagaan jadi usahawan memerlukan back-up plan atau perancangan kedua bagi menangani risiko kerugian kerana dalam pasaran akan wujud produk yang sama yang menjadi pesaing.

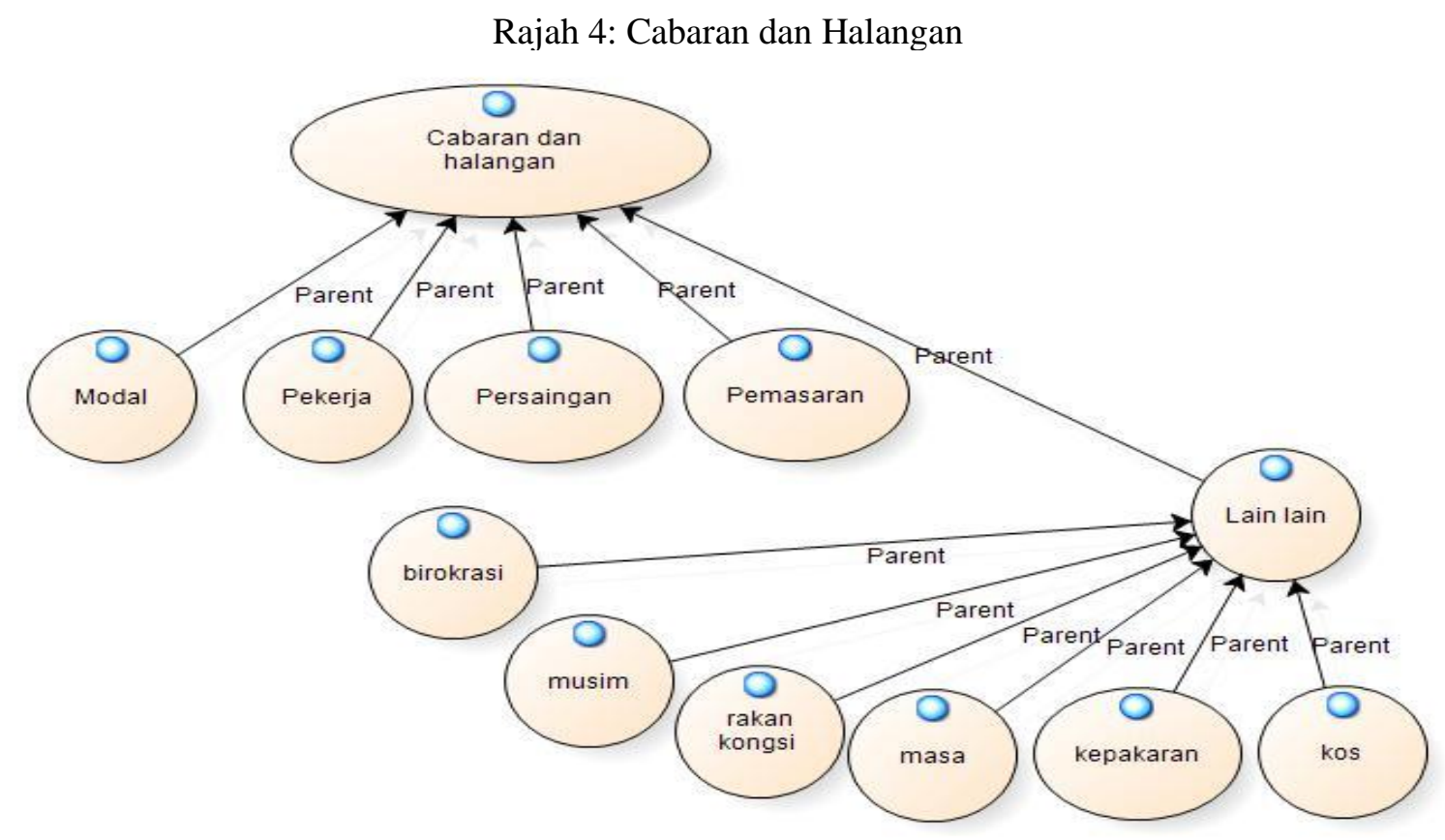

Masalah pemasaran pula kebanyakan usahawan hanya berada pada kelompok pasaran yang kecil small market dan ini akan menyebabkan promosi mereka kurang berkesan kerana terlalu banyak pesaing yang mempunyai pasaran lebih besar daripada perniagaan mereka. Lain-lain cabaran dan halangan yang dinyatakan oleh usahawan yang ditemu bual ini antaranya adalah terpaksa berhadapan dengan karenah birokrasi yang melambatkan proses perniagaan, keadaan musim yang tidak menentu, masalah rakan kongsi yang hanya menyumbang modal tetapi tidak mahu bekerjasama dalam pengurusan perniagaan (rakan kongsi lelap), masa yang terhad, kurang kepakaran dalam beberapa bidang dan terpaksa menanggung kos yang tinggi.

\section{Kesimpulan}

Secara umumnya juga, tidak ramai graduan yang melibatkan diri dalam aktiviti keusahawanan ketika di IPT namun disebabkan oleh faktor-faktor lain seperti sikap, latar belakang, motivasi dan kemahiran yang telah mendorong mereka untuk menjadi seorang usahawan sehingga kini. Kebanyakan daripada usahawan memulakan perniagaan selepas mengambil masa beberapa tempoh tertentu seperti setahun sehingga 4 tahun selepas tamat pengajian untuk menimba pengalaman dengan bekerja terlebih dahulu sebelum memulakan perniagaan sendiri. Pemilihan jenis perniagaan juga memainkan peranan penting dalam memastikan kejayaan sesuatu perniagaan tersebut. Hasil dapatan analisis mendapati lebih ramai usahawan yang menjalankan perniagaan berdasarkan minat dan kemahiran yang mereka peroleh. Selain itu tanpa adanya faktor yang pendorong yang kuat yang menyokong mereka daripada belakang maka mereka tidak akan menceburi bidang keusahawanan ini. Perkembangan perniagaan setiap usahawan menunjukkan potensi yang memberangsangkan daripada aspek perubahan dan pembaharuan yang dilakukan ke atas perniagaan mereka. Setiap perancangan yang direncanakan oleh mereka juga 
mempunyai hala tujunya yang tersendiri dalam mencapai objektif perniagaan. Namun bagi menjalani perkembangan dalam perniagaan adalah bukan mudah, ianya memerlukan semangat yang kental dalam mengharungi cabaran dan halangan. Pelbagai cabaran dan halangan yang ditempuhi oleh mereka untuk menjadi seorang usahawan yang berjaya. Perkembangan juga tidak akan tercapai tanpa adanya sifat atau ciri-ciri seorang usahawan dalam diri seperti agresif, mempunyai rangkaian atau networking, berwawasan dan mempunyai kemahiran dalam pengurusan kewangan serta perniagaan yang menjadi faktor penyumbang utama kepada kejayaan usahawan.

Diharapkan agar pihak Kementerian Pengajian Tinggi dapat memainkan peranan dengan menyediakan bajet atau peruntukan dana dan modal kepada golongan graduan yang betul-betul berminat untuk menjadi usahawan. Mengadakan program keusahawanan, mewujudkan satu jaringan keusahawanan melalui laman web, peruntukan untuk bengkel dan kursus keusahawanan, mengadakan lebih banyak program kesedaran kerjaya keusahawanan dan memberi pinjaman berbentuk modal kepada graduan yang ingin menjadi usahawan. Selain itu menyediakan tenaga pengajar atau pensyarah yang benar-benar mempunyai pengalaman dalam bidang keusahawanan untuk diberi pendedahan melalui pengalaman mereka kepada pelajar dan pendedahan awal kepada graduan bagi mengenal erti risiko dalam perniagaan daripada awal. Selain itu, Institusi Pengajian Tinggi juga diharapkan agar melibatkan dan menggalakkan pelajar untuk berniaga dengan menyediakan tapak perniagaan untuk pelajar bagi memulakan perniagaan terutamanya ketika majlis konvokesyen. Memberi pendedahan melalui latihan praktikal untuk melatih graduan dalam dunia sebenar perniagaan. Memberi pengetahuan kepada mahasiswa mengenai unsur-unsur perniagaan yang boleh diceburi mengikut bidang yang dipelajari supaya mereka mudah mengambil keputusan jenis perniagaan yang bersesuaian dengan kemahiran yang mereka peroleh. Menjemput usahawan yang telah berjaya datang ke IPT dan berkongsi pengalaman dengan pelajar. Membimbing graduan yang betul-betul berminat untuk menjadi usahawan sehingga menjadi seorang usahawan yang berjaya.

Oleh yang demikian, para pengkaji pada masa depan perlu menjalankan kajian tentang impak programprogram keusahawanan yang telah dijalankan di IPT (program yang ditawarkan). Fokus kajian yang perlu dijalankan ialah mengenal pasti keberkesanan program keusahawanan yang dijalankan serta faktor yang menyebabkan kurangnya penglibatan graduan dalam program keusahawanan yang dianjurkan dan cara pengimplimentasian yang sesuai dalam mengendalikan isu ini. Kajian pada masa depan juga boleh dilakukan dengan menjalankan kajian susulan yang lebih komprehensif terhadap graduan yang bekerja sendiri daripada data Kajian Pengesanan Graduan dan mengkaji tahap kompetitif seseorang usahawan graduan.

\section{Rujukan}

Berita Harian, (2010). Kementerian Pengajian Tinggi (KPT) menyasarkan, sekurang-kurangnya lima peratus lepasan IPTA menceburi bidang keusahawanan. Diperolehi pada 5 Oktober 2 010. Dari www.bharian.com.my.

Hanim Sulaiman, Mohd Hassan Mohd Osman \& Khairul Nisak Othman. (2009). Perlaksanaan Program Tunas Bistari Dalam Pembangunan Budaya Keusahawanan Di Sekolah-Sekolah Menengah Di Daerah Johor Bharu. Johor. Fakulti pendidikan. Universiti Teknologi Malaysia.

Hanim Sulaiman, Mohd Hassan Mohd Osman \& Mohd Lutfi Mohd Raffi. (2010). Perbandingan CiriCiri Kompetensi Keusahawanan di antara Pelajar yang Mendapat Pendedahan Formal Dengan Pelajar yang Tidak Mendapat Pendedahan Formal di dalam Bidang Keusahawanan di University Teknologi Malaysia. Fakulti pendidikan. Universiti Teknologi Malaysia.

Kementerian Pengajian Tinggi. (2008). Laporan Kajian Pengesanan Graduan 2008. Kementerian Pengajian Tinggi. Kuala lumpur.

Kementerian Pengajian Tinggi. (2007). Mentransformasikan Pengajian Tinggi melalui Pelan Strategik Pengajian Tinggi Negara (PSPTN): Projek Agenda Kritikal (CAP). Kementerian Pengajian Tinggi. Kuala lumpur.

Kent, C. E. (1990). Predictable books for preliterate peoples. SIL International.

Khaairuddin Khalil. (1996). Keusahawanan Sebagai Kerjaya. Kuala Lumpur: Dewan Bahasa dan Pustaka. 
Mazdan Ali Amaran. (2011). Pembudayaan Keusahawanan dalam Kalangan Graduan (Tesis tidak diterbitkan). Kuala Lumpur: Universiti Malaya.

Mohd Hassan Mohd Osman. (2007). Faktor-Faktor yang telah Mendorong Graduan dan Alumni University Teknologi Malaysia Menceburi Bidang Keusahawanan. Fakulti Pengurusan dan Pembangunan Sumber Manusia. Universiti Teknologi Malaysia.

Ronstadt, R. (1985). The Educational Entrepreneurs: A New Era of Entrepreneurship Education is Beginning. American Journal of Small Business, 10(1).

Shahrin Hashim \& Hemalatha. (2010). Persepsi Pelajar Tahun 4 SPH (Ijazah Sarjana Muda Teknologi serta Pendidikan)(Kemahiran Hidup) terhadap Bidang Usahawan Siswa. Fakulti Pendidikan . Universiti Teknologi Malaysia.

Wang, C. K. \& Wong, P. K. (2004). Entrepreneurial interest of university students in Singapore. Singapore Journal of Technovation, 24, 163-172.

Yep Putih. (1985). Keusahawanan Edisi Pertama. Kuala Lumpur. Dewan bahasa dan Pustaka.

Zafir Mohd Makhbul \& Fazilah Mohamad Hasun (2003). Menjadi Usahawan. PTS Publications \& Distributor Sdn. Bhd. 